Araştırma Makalesi / Research Article

\title{
ABD VE ÇIN ARASINDAKİ TİCARET SAVAŞI: REKABET GÜCÜ VE REEL KUR AÇISINDAN BİR DEĞERLENDIRME
}

\author{
Ziya Çağlar YURTTANÇIKMAZ* \\ Ömer Selçuk EMSEN ** \\ THE TRADE WAR BETWEEN USA AND CHINA: AN \\ EVALATION IN COMPETITION POWER AND THE REAL \\ EXCHANGE RATE
}

Öz

Çin ile ABD arasında ortaya çıkan ticaret savaşı olgusu, tarihsel köken itibarıyla neo-merkantilizm olarak adlandırılmaktadır. ABD uyguladığı merkantilist politika uygulamaları ile ekonomisini koruma amacı gütmektedir. ABD'nin iddiası, Çin'in haksız rekabet unsurları ile dış ticarette aleyhte bir yapı ortaya çıkardığı yönündedir. Çin ise ABD'nin merdiveni itme güdüsü ile kendini korumaya çalıştı̆̆ını vurgulamaktadır. Çalışmada ABD’nin argümanı olan kura dayalı rekabet olgusu ile Çin'in maliyete dayalı rekabet konusu ekonometrik analizlere tabi tutulmuştur. Elde edilen analiz sonuçlarına göre Çin'in ABD ile olan diş ticaretinde çeşitli mamul eşya (SITC-8) grubunda en yüksek rekabet gücüne sahiptir. Bunu sırasıyla, başlıca sınıflara ayrılan işlenmiş mallar (SITC-6), makine ve taşı araçları (SITC-7) mal grupları takip etmektedir. Elde edilen bulgularda Çin'in sadece döviz kuruna dayalı bir rekabet gücü olmadığı; sermaye birikimi ve rekabet gücündeki iyileşmelerin ihracatını artırmada önemli rol oynadığı sonucuna ulaşılmıştır.

Anahtar Kelimeler: Ticaret Savaşları, Rekabet Gücü, Zaman Serisi Analizi.

\begin{abstract}
The phenomenon of trade war between China and the United States is called by neo-mercantilism in its historical origin. The US aims to protect its economy through the implementation of mercantilist policy. The United States' thesis is that China has created an unfavorable structure for unfair competition and foreign trade. On the other hand, China stresses that the US is trying to protect itself by kicking away the ladder. In this study, the phenomenon of the exchange rate-based competition, which is the argument of the USA, and the cost-based competition,
\end{abstract}

* Dr. Öğr. Üyesi, Atatürk Üniversitesi, İ̈BF, e-posta: ziya@atauni.edu.tr, https://orcid.org/0000-0001-7474-1096.

** Prof. Dr., Atatürk Üniversitesi, İİBF, e-posta: osemsen@atauni.edu.tr, https://orcid.org/0000-0002-1809-0513.

Makale Gönderim Tarihi: 04.02.2020 https://doi.org/10.11616/basbed.v20i58861.684405 Makale Kabul Tarihi $\quad: 10.12 .2020$ 
which is the argument of China are subjected to econometric analyzes. According to the results of the analysis, China has the highest competitiveness in the foreign trade in the various manufactured goods (SITC-8) group. This is followed by processed goods (SITC-6), machinery and vehicles (SITC-7), which are divided into major classes, respectively. The findings show that China is not only a competitive power based on exchange rate, but also that improvements in capital accumulation and competitiveness play an important role in increasing exports.

Keywords: Trade War, Competitiveness Power, Time Series Analyses.

\section{Giriş}

Yaygın iktisat jargonu ülkelerin liberal ekonomi politikaları uygulamalarının işbölümü ve uzmanlaşmayı sağlayarak dış ticaret yoluyla refahlarının maksimum olacağını ileri sürer. Burada işbölümü ve uzmanlaşma mantığında ülkelerin üstün oldukları ve dolayısıyla dünya fiyatlarının altında ürettikleri malları dış pazarlara açmak suretiyle görece daha yüksek gelir elde edecekleri ve buna karşılık dezavantajlı olup yüksek maliyetle ürettikleri malları da daha ucuza ithal ederek daha fazla tüketimde bulunacakları iddia edilir. Böylece hem geliri hem de tüketimi artan ülkelerin genel denge yaklaşımı mantı̆̆ 1 çerçevesinde refahlarının artacağ kabul edilir. Özellikle dış ticarette liberal söylemleri savunan ülkelerin daha çok gelişmiş ve anti liberal söylemlerin ise az gelişmiş ve gelişmekte olan çevrelerde taraftar bulması bir tür olağan kabul edilebilir. Günümüzde $\mathrm{ABD}$ tarafından korumacı politikaların yürütülmesi ve Çin'in serbestleşmeyi destekler söylemleri, küresel anlamda sıra dışı bir dönemin yaşandığ şeklinde yorumlanmaktadır. Ancak, ilk etapta gözlenen bu sıra dış1lık, sanayileşmenin tarihi perspektifinden bakıldığında, daha belirgin bir şekilde görülmektedir. Diğer bir ifadeyle aslında rekabet gücünde önde olan ülkelerin serbestiyeti, buna karşıllk rekabet gücünde geride kalan ülkelerin ise korumacillğa yönelimi yeni bir olgu değildir. Anti liberal söylemler yaklaşık iki asır öncesinin ABD'sinde A. Hamilton ve Almanya'da F. List'in geliştirmiş oldukları genç endüstriler argümanında daha belirgin bir şekilde ortaya çıkmıştır. Günümüzde de bu durum 20 . yüzyılın ikinci yarısında Japonya ve G. Kore'ye varıncaya kadar birçok ülke tarafından uygulanan politikalarda gözlenmiştir. Hatta liberal söylemde olanların liberalizm savunuculuğunun rekabet güçleri zirvedeyken ortaya konulduğu ve bu davranışlarının "merdiveni itme" kavramıyla tanımlanmalarına yol açtıkları; buna karşıllı rekabet gücünü kaybettiklerinde korumacilığa yönelmelerinden hareketle ileri sürülmektedir (Chang, 2015: 24; Chang, 2004: 9). Dolayısıyla gelişmiş̧lerin gelişmekte olan ve az gelişmiş ülkelere dayattıkları politikaların kendi geçmişlerinden farklı oluşu, merdiveni itme olarak nitelendirilen olgunun varlığını akla getirmektedir. İlk defa List tarafından 
dile getirilen merdiven itme mekanizması, "zengin bir ülkenin zirveye ulaştığında, diğerlerinin kendisinden sonra tırmanmasını engellemek için, oraya tırmanmasını sağlayan merdiveni geri itmek" şeklinde ifade edilir olmuştur (Chang, 2004: 9).

Üretimin küreselleşmesi mantığında zımnen başta Çin olmak üzere çoğu gelişmekte olan ülkeye biçilen kaftan, daha çok gelişmiş ülkeler için kârlı olmaktan çıkan üretim alanlarında faaliyette bulunma ve gelişmiş ülkelere ucuz mal temin etmeleridir. Özellikle güçlü nüfus yapısı ile Çin'in bu fonksiyonu daha iyi icra edeceği düşünülmüştür. Zira Çin'in komünizm altında geçen yılları sosyalizmin ütopyaları ile büyük bir sıçramanın nasıl sağlanacağına dair arayışlar tam bir facia ile sonuçlanmıştı. Nisan 1977'de daha önce Mao eliyle yürütülen "İleri Atılım” uygulaması Deng Xioping ile daha sonraları "Dışa Doğru Atılım" adı altında uygulamaya konulmuş ve günümüzde ulaşılan başarının temellerini oluşturmuştur (Acemoğlu ve Robinson, 2014: 34-44). Dolayısıyla İleri Atılım adı verilen sosyalizm ütopyası ancak Mao'nun ölümünden sonra benimsenen "açık kapı politikası" ve buna uygun olarak ihracata yönelik sanayileşme politikası ile birlikte ekonomik anlamda "Çin mucizesi"nin de ortaya çıkmasını doğurmuştur. Çin'in ucuz emek avantajından dolayı (Coase ve Wang, 2015: 3) gelişmiş ülkeler de bu mucizenin gerçekleşmesinde hem yaptıkları sermaye yatırımlarıyla "doğrudan" hem de ucuz mallara gösterdikleri taleple "dolaylı" destek olmuşlardır.

Çin'in beklenen formatının dışına çıkmaya başlaması, yani düşük katma değerli ve emek-yoğun mal üretip dünyaya enjekte etme fonksiyonu, yani "yoksul ve boş" geri tarımsal bir ülkeden komple endüstriyel kategorilere sahip bir dünya sanayi ülkesine dönüşüm sağlanarak adeta gerçek bir "dünya fabrikası" konumuna geçmiştir. Aslında Çin için bu aşama başta ABD olmak üzere Batılı kapitalist ülkeler için ideal bir durum olarak tanımlanabilir. Aralık 2001'de Dünya Ticaret Örgütü'ne katıldıktan sonra, ekonomik küreselleşmeye derinlemesine entegre olan Çin, karşılaştırmalı üstünlüklerini tamamen kullanmış ve "yaparak öğrenme" yoluyla endüstriyel yükseltmeyi teşvik etmiş ve sanayileşme sürecini daha da hızlandırmıştır (Liu, 2004, 22). Diğer taraftan sanayi ve üretimin sermaye ve teknoloji yoğunluğu ise artmaya devam etmiştir. Şöyle ki, teknoloji yoğun endüstrilerin üretim değeri, 10. Beş Y1llık Plan döneminde ortalama sanayi üretim değerinden yaklaşık \%2 daha yüksek olmuştur. 2013 yılında, Çin'in yüksek sanayi sektörünün GSYİH'ye katma değeri $(\% 46,1)$ ilk kez ikincil sanayiyi $(\% 43,9)$ aştı ve ulusal ekonomideki en büyük sanayi sektörü oldu. Büyüme oranı açısından, üçüncü sanayi de ikincil sanayiyi geçmeye başlamış, ekonomik büyümeyi yönlendiren ve tam istihdam sağlayan ana güç haline gelmiştir. Son 70 ylldaki sanayileşme süreci 
boyunca, birincil sanayinin katma değerinin oranı 1952 'de $\% 50,5$ 'ten 2018'de \%7,2'ye; ikincil sanayinin katma değeri 1952 'de $\% 20,8$ 'den 2006'da \%47,6'ya yükselmiş ve ardından da düşmeye başlamış, 2018'de $\% 40,7$ olmuştur. Üçüncül sanayinin katma değeri ise 1952 'de \%28,7'den 2018'de \%52,2'ye çıkmış ve yükselmeye de devam etmektedir. Şu anda, Çin sanayileşmenin geç aşamasına girmiştir ve 2035'ten sonra sanayileşmenin tam olarak gerçekleşmesi beklenmektedir ve bu da dünyadaki üretim güçlerinin orta seviyesine ulaşma anlamı taşır (Reziwanguli, 2019: 55). Muhtemeldir ki, Çin'den beklenen fonksiyon olan emek-yoğun alanlarda dünyaya mal arz etme kapasitesinin henüz sonuna gelmemiş olmasına rağmen, hızlı bir şekilde sermaye ve teknoloji yoğun alanlara yönelimi tehdit olarak algılanır olmuştur. Çin'in emekyoğun büyümenin sınırlarına gelmeden sermaye ve teknoloji yoğun alanlara kayma göstermesi, yüksek büyümesi ve dış fazlacı yapısı (Steinbock, 2018), ABD'de Çin'i frenleme gayretini artırmıştır. Bu noktada, Haziran 2017'de Trump'ın ulusal güvenlik endişesi ile çelik ve alüminyumda başlattığ1 "Bölüm 232 Soruşturması" ve devamında da 2018 yılı Ocak ayında ABD'nin Çin'e yönelik ticari kısıtlamalara yönelmesi (ABD'nin \%10 ila \%50 arasında tarife uygulamaya giderek Çin ihracatının 283 milyar dolarlık kısmına yönelik) söz konusu olmuştur. Buna Çin'in de 16 Haziran 2018'de mütekabiliyet, yani kısasa kısas ilkesi çerçevesinde cevap vermesi (Çin'in \%16 tarife uygulamaya giderek ABD ihracatının 121 milyar dolarlık kısmına yönelik) ticaret savaşları olarak tanımlanan olguyu gündeme taşımıştır (Amiti vd., 2019; Mallick, 2018: 3). Aslında ticaret savaşlarının kökeni kadim bir iktisat doktrini olan Merkantilizmde yer bulmuştu. Başlangıçta Merkantilist düşünceyi çağrıştırsa da, korumacılığın standart aracı gümrük tarifeleridir ve tarifeler de dış açık veren ABD'nin diğer dış fazla veren ülkeleri ihmal ederek 2001'de Dünya Ticaret Örgütü (DTÖ)'ne üye olan sadece Çin'e yoğunlaşması nedeniyle, çalışmanın başlı̆̆ını "ticaret savaşları" olarak değil, "ticaret savaşı" olarak betimlemek daha doğru olmuştur. Çin'e yönelik uygulama gelişmişin gelişmekte olana yönelik diş ticarette uygulamaya soktuğu ilk kısıtlama değildir. Genel olarak korumacılığ savunan gelişmekte olanlar olduğuna dair inanca karşıllk, zaman zaman gelişmişin anti-merkantilist uygulamalara yönelmeleri örneği olarak ortaya çıkan ABD-Çin motifi, geçmişte Japonya'ya karşı ABD tarafindan ortaya konulan kısıtlama benzeri bir davranış olarak ortaya çıkmaktadır. Japonya'ya yönelik uygulamada iç pazardaki üreticileri ve faktörleri koruma amacı taşımakta iken, şu anda Çin'e doğru yapılan baskılamanın yukarıda da belirtildiği gibi, özellikle Çin ekonomisinde ortaya çıkan devasa sıçrama ve ona biçilen rolde sapmanın yansıması olarak görülebilir. Çin'e biçilen rol emek-yoğun ve düşük katma değerli mallar iken, onun dünya ekonomisine 
yönelik ihracatının yüksek teknolojik mallara evrilen (Aksu vd., 2018: 5) yapısına paralel olarak dünya ekonomisinde bir numara olma yolundaki gidişatı kuvvetle muhtemel bir tehdit olarak algılandığı düşünülebilir.

Çalışmada Çin'in sanayi malları ihracatında rekabet gücü ile reel kur açıklayıcı değişkenler olmak üzere sanayi malları ihracatına bu iki değişkenin etkilerinin araştırılması hedeflenmiştir. Böylece Çin ekonomisinin kur gibi suni yollarla $m ı$ ihracatta pazarını genişlettiği, yoksa ciddi anlamda rekabetteki gelişmelerle mi ihracatını artırdığı incelemeye değer bulunmuştur. Aslınca kur silahı suni bir rekabet gücü elde etme aracı olarak kabul edildiğinde, Çin'in ihracatında kur etkisi kuvvetle muhtemel ticaret savaşında ABD'yi haklı gösterecek motif olarak kabul edilebilir. Buna karş1lı rekabet gücünün ihracat üzerine etkisinin ortaya çıkması ise ABD'nin haksız uygulamalar içinde olduğunu ortaya koyacaktır. Bu çerçevede çalışmanın ikinci kısmında ticaret savaşının bir tür merdiveni itme davranışı olduğu incelenmiştir. Üçüncü kısımda ticaret savaşındaki gelişmeler ve dördüncü kısımda ticaret savaşının yansımaları üzerine literatür incelemesi özet olarak verilmiştir. Literatürün genel anlamda ticari yaptırımların yansımaları üzerine yoğunlaştığı dikkati çekerken, ABD'nin tezinin gerçekçiliğini araştırmaktan uzak, sadece konuyu betimleyici istatistiklerle açıklayarak geçiştirildiği görülmektedir. Beşinci kısımda ise rekabet gücüne göre avantajlı sektörler belirlenerek, bu avantajlı sektörlerde ihracatta rekabet gücü ile reel kurun etkileri araştırılmıştır. Altıncı kısımda ise sonuç ve politika çıkarımına gidilmiştir.

\section{Ticaret Savaşı Bir Merdiveni İtme Davranışı mı? Neo- merkantilizm Ĕğilimleri}

Çin, 2018 yılı başından itibaren ABD tarafından uygulanan korumacı politikalara karşı çıkmış ve 10 . BRICS zirvesinde başkanının yaptığı konuşmada ticaret savaşının kazananı olmayacağı ifade edilmiştir. Buna karşl1ık, pasif kalmaktan ziyade, ilerleyen dönemlerde bir tür mütekabiliyet ilkesi çerçevesinde ABD'nin politikalarına karşılık verme yolunu da seçmiştir. Bu noktada Çin bir taraftan serbest ticareti savunurken, aslında diğer taraftan kendisi de neo-merkantilist politikaların uygulayıcısıdır. Çin'in bu neo-merkantilist politika uygulamaları ABD gibi gelişmiş ülkelerde 'inovasyon merkantilizmi' olarak adlandırılırken, kaynak sahibi gelişen ülkeler ile olan ilişkilerinde ise 'enerji merkantilizmi' biçiminde gerçekleşmektedir. İnovasyon merkantilizmi çerçevesinde uygulanan politikalar, küresel ekonominin refah düzeyini azaltmak pahasına, uygulayıcısı olan ülkede yüksek ücretli endüstriler ve iş kolları geliştirmeye yönelik politikalar olarak tanımlanmaktadır (Ezell ve Atkinson, 2011: 11). Ülke, inovasyona dayalı ihracatını arttırmak için 
döviz kuru manipülasyonu yapmakta, haksız rekabete yol açıcı piyasa ve fikri mülkiyet hakları uygulamalarında bulunmaktadır. Diğer bir ifadeyle bu politikaları uygulayan ülkeler ticaret bozucu politikalar yoluyla küresel üretim zincirinde yüksek katma değerli üretim aşamalarına geçmektedirler (Cory, 2018). Çin'in Orta Asya, Ortadoğu, Afrika ve Latin Amerika'da uyguladığı politikalar ise enerji merkantilizmi politikası olarak tanımlanabilir. Enerji merkantilizmi politikaları, Çin ekonomisinin enerjiye bağımlı yapısına dayanmakta olup enerji sağlamada yaşanabilecek olası aksaklık karşısında ekonominin kırılganlığını azaltmayı hedeflemektedir (Lind ve Press, 2018: 7). Çin'e yönelik ABD tarafından ileri sürülen suçlamalarda enerji merkantilizmi uygulamaları ile kur ve ücret baskısı ile avantaj elde etmesinin yanı sıra çevre tahribatını dikkate almayan uygulamalarda bulunması sayılmaktadır.

Ticaret savaşları olgusu tarihsel kökenleri itibarıyla Merkantilist düşünceye kadar geride olsa da, ABD ile Çin arasındaki durum, 2018'de değil, 1991'de fikri mülkiyet hakları, haksız ticaret engelleri ve temiz enerji alanlarını araştırmak üzere açılan soruşturmalara kadar geriye gitmektedir. Bunlar da beş "Bölüm 301" olarak nitelendirilmiştir (Zhu vd., 2018: 423; Meltzer ve Shenai, 2019: 2). Bu çatışmacı yapı daha çok diplomatik yollardan çözülürken, genel olarak DTÖ politikaları ekseninde yapılan anlaşmalarla tıkanıklıklar aşılıyordu. Benzer şekilde ABD'nin Avrupa Birliği ve Japonya'ya karşı II. Dünya Savaşından sonra 1951'de başlattığı ticareti kısma hareketleri kronolojik olarak önce hafif sanayi, 1970'lerde çelik sanayi, 1980'lerde otomotiv sanayi ve sonrasında da elektronik ürünlere uygulanmış; Japonya'nın “gönüllü ihracat kısıtlamaları"nda bulunması ile aşılmıştı (Chong ve Li, 2019: 5-6, 9). İlk defa Japonya'ya karşı uygulanan gönüllü ihracat kısıtlamalarına aynı zamanda ihracat kotaları adı verilmektedir. İthalatçı konumundaki gelişmiş bir sanayi ülkesinin kendi iç piyasasını bozduğu gerekçesiyle bunları ihraç eden gelişmekte olan ülke ihracatı üzerine konulan miktar kısıtlamalarıdır; "ihracat kotası" olarak da adlandırılır. İthalat kotalarından fark1, kısıtlamaya ihracatçının kendisini gitmesindendir. Yeni korumacılık türü olarak bilinen bu uygulamaya 1950'lerde ilk kez Japonya'ya karşı ABD tarafından uygulanmıştır (Seyidoğlu, 2013).

Aslında Çin'in 1980'lerdeki açık kapı politikası başta ABD olmak üzere gelişmiş Batılı ülkelerce desteklenirken, 1980'ler ile 1990'larda Çin'den ABD'ye ithalat da oyuncaklar ve oyunlar, tüketici elektronik ürünler, ayakkabı ve tekstil ile konfeksiyon gibi düşük katma değerli emek-yoğun ürünlerden oluşuyordu. Bununla birlikte geçen birkaç y1l süresince ABD'nin Çin'den yaptığı ithalatın artan bir kısmı teknolojik olarak daha gelişmiş ürünleri kapsamaya başlamıştır ki, yüksek teknolojik mal 
ithalatının toplam ithalattaki payı \%33.8'e ulaşmıştır (Mallick, 2018: 11). Burada ticaret savaşı olgusunda partner ülkeye karşı uygulanan tarifeler yoluyla teklif eğrisinin sola kaydırılması hedeflenmekte ve böylece ticaret hacmi daraltılırken, ticaret hadleri ülke lehine çevrilmeye çalışılmaktadır. Teklif eğrileri yaklaşımında, ticaretteki artışlar refahı olumlu etkilerken, ticaret artışına bağlı olarak ticaret hadlerindeki bozulmalar ise refahı olumsuz yönde etkilemektedir. Ticaret hacmi ile haddinde ortaya çıkan iki zit etkinin toplamı ise net etki ya da refah etkisi olarak nitelendirilir. Ancak, bir ülkenin bir ülkeye karşı ticari kısıtlamaları başlatması, sadece iki ülke arasındaki bir ilişki şeklinde yalıtılmış bir sonuç doğurmayacaktır. Dış ticaret teorisinde yayılma, bulaşma veya domino etkileri diye ifade edilecek bir durum ortaya çıkacaktır. Burada Çin'in ihracatını azaltıcı politika uygulamaları şüphesiz Çin ulusal gelirinin potansiyel büyümesinin altında kalması ve bu da Çin'in ticari partneri olan ülkelerden dış alımını kısmasını tetikleyecektir. Çin'in ithalatı ise partner en büyük beş ülkenin (AB, ASEAN ülkeleri, G. Kore, Japonya ve Çin Tayvan'1) ihracatı anlamına gelmekte, bu durum da partner ülkelerin ulusal gelirinde potansiyelin altında bir büyüme sonucunu doğurarak, bu partner ülkelerin de kendisi ile ilişkili ülkelerin ihracat ve gelirlerini sekteye uğratması sonucunu doğuracaktır. Diğer taraftan ticaret savaşı uygulamasında optimum tarife uygulamasına giderek teklif eğrisini karşı ülke teklifine yaklaştırma eğilimi ile görece daha az ihraç malı ve daha fazla ithal malı elde etme eğiliminin dışında, monopson olma konumuna bağlı olarak vergilerin yansıtılmasını sağlama eğiliminden de bahsedilebilir. Zira monopsonist yapıda talep esnekliği açısından ithalatçı ülke avantaj elde edebilmektedir ve ABD'nin refah etkilerinin kesin olarak ortaya çıkması gibi bir beklentinin varlığından da bahsedilebilir (Amiti vd., 2019: 4).

\section{Ticaret Savaşındaki Gelişmeler}

Çin ile ABD arasında ortaya çıkan ticari gerginlik veya ticaret savaşı Nisan 2018 yılında ABD'nin Çin çelik ve alüminyumuna karşı tarife uygulamaya gideceğini açıklaması ve bunun zaman dilimi içerisinde genişletmesi ve derinleştirmesi ile kendini göstermiştir. Bunun öncesinde Mart 2018'de ABD'nin $A B$ ve NAFTA ülkeleri de dahil bütün ülkelerden ithal ettiği çelik ve alüminyum ithalatına gümrük vergisi uygulamaya gideceğini bildirmişti. $\mathrm{Bu}$ bildirge üzerine $\mathrm{AB}$ de misillemede bulunmak amaciyla DTÖ’ye ABD mallarına \%25 vergi uygulayacağına dair bir liste sunmuştu ki, bu durum yayılma etkilerine örnek teşkil etmektedir (Bollen ve RojanRomagosa, 2018: 6).

Çin ile ABD arasındaki son dönemdeki ticari açıdan ortaya çıkan durumu da Gros (2019) bir ticaret savaşından ziyade, jeo-stratejik baskınlık ve 
teknolojik mücadele olarak tanımlamakta ve hatta (Bekkers vd., 2019) ticari çatışma olarak dahi ifade edilmektedir. Bu noktada ticaret savaşı ülkeler arasında işbirliğine dayalı ticari ilişkilerde veya ülke koalisyonlarında bir bozulma olarak nitelendirilir. Ortaya çıkan cari duruma göre ABD'nin sorunu, verdiği ticaret açığının kökenini ihmal etmesinden kaynaklanmakta; ticari açığın genel olarak yurtiçi yatırım ve tasarruf açığının bir yansıması olduğu görmezden gelinmektedir. Buna göre ticareti kısıcı önlemlerin kökeni olan tasarruf-yatırım ilişkileri ihmal edildikçe, ticaret açığını kapatmaya yönelik önlemlerin bunu çözmeyeceği ve dolayısıyla potansiyel olarak açı̆̆ın devam edeceği ileri sürülmektedir. ABD ile Çin arasındaki ticari ilişkiler başta olmak üzere 2018 yılına ilişkin olarak ABD, Çin, Euro Bölgesi ve Japonya verileri üzerine yapılan incelemede Çin'in diş ticaret fazlası (GSYIH'ya oranı \%4.4) ve ABD'nin de diş ticaret açığı (GSYIH'ya oranı\%-4.0) vermiştir. Hizmet dengesinde ise Çin'in dış açı (GSYIH'ya oranı \%-2.2) ve ABD'nin ise dış fazla (GSYIH'ya oranı \%1.3) verdiği ve netice itibarıla mal ve hizmet bilançosunun GSYIH'ya oranının ABD'de \%-2.5 ve Çin'de ise \%0.3 olduğu gözlenmiştir. Bütün bunlara ilaveten Euro bölgesinin ve Japonya'nın dış ticaret ve hizmet dengesi de sırasıyla \%4.1 ve $\% 0.5$ ile $\% 1.0$ ve \%-0.2 olarak gerçekleşmiştir. Dolayısıyla Euro alanında hem mal hem de hizmetler dengesi açısından ortaya çıkan açık ihmal edilip de, Çin'in mal fazlası ve hizmet açığı ihmal ediliyorsa, o zaman ticaret savaşları değil, Çin'e karşı ticaret savaşı kavramı kullanılsa daha yerinde bir durumdan bahsedilebilir (Gros, 2019: 21). Ticaret savaşı kavramı veya misillemeler olgusunda Çin'in kur politikası yoluyla haksı rekabet avantajı elde ederek dış ticaret fazlası ve buna dayalı yüksek büyümesini ucuz/baskılanmış işgücü ve çevre tahribatı ile gerçekleştirdiği iddiaları dikkat çekmektedir. Aşağıdaki şekillerde ABD ile Çin'in 1960'dan 2018 yılına kadarki süreçte mal ve hizmet ihracatının ve ithalatının GSYIH'ya oranları verilmiştir. 
Şekil 1: Çin ile ABD'nin Mal ve Hizmet İhracat ve İthalatlarının GSYİH'ya Oranları

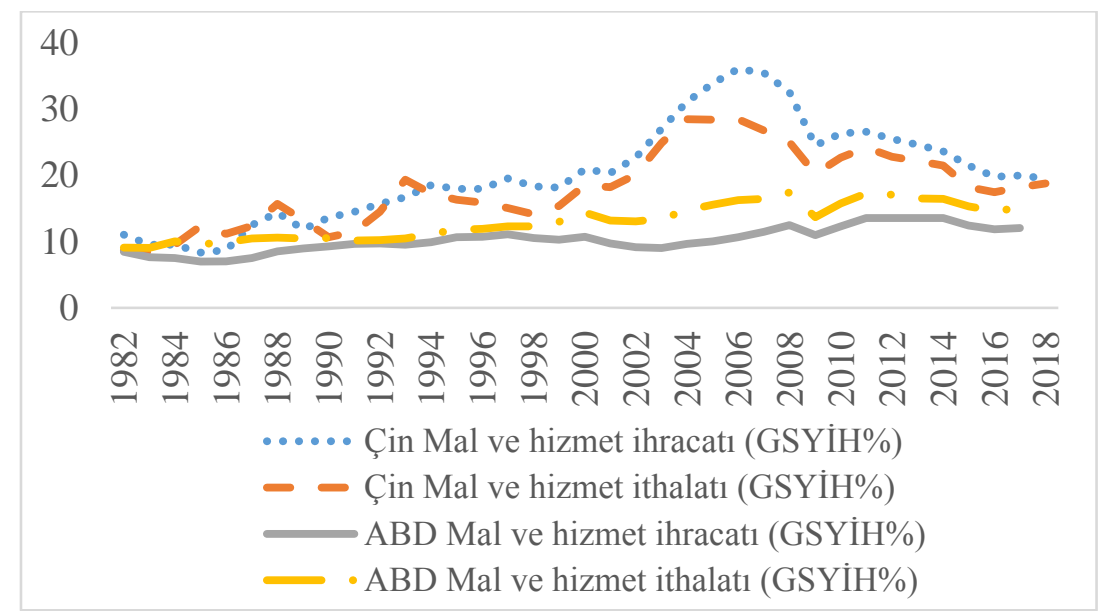

Şekil 1 incelendiğinde1990'lardan itibaren Çin'in mal ve hizmet ihracat ve ithalatın GSYIH'ya oranlarının, yani dışa açıklık oranlarının ABD'yi geçtiği gözükmektedir. Diğer taraftan Çin'in genel anlamda cari fazla veren ve ABD'nin ise cari açık veren bir ülke olduğu dikkat çekmektedir. ABD'nin sürekli cari açık veren bir ülke olmasına yol açan unsurların başında tasarruflardaki yetersizlikler gelmektedir. ABD gibi tüketim toplumları tasarruf yetersizliği içerisinde kalmakta ve bu türden toplumlar "Veblenist toplumlar" olarak nitelendirilmektedir. Buna karşılık tüketimden ziyade tasarruflara ve bunu da yatırımlara kanalize eden Çin gibi toplumlar da "Konfüçyen toplumlar" olarak tanımlanmaktadır. Veblenist toplumlarda büyümenin dinamiğini iç tüketim-piyasa oluşturmakta iken, Konfüçyen toplumlarda büyümenin dinamiğini yatırımların sürüklediği üretim ve dış piyasalar oluşturmaktadır (Emsen, 2009). Buna ilaveten her iki ülke de dünyada en fazla yabancı sermaye çeken ülke konumundadır. ABD tüm dünyada ve gelişmiş ülkeler arasında birinci; Çin ise tüm dünyada ikinci ve gelişmekte olan ülkeler arasında birinci konumdadır. Çin'in sermaye çekimi üretimi destekleyici nitelikte iken; ABD'nin sermaye çekimi daha çok rant motifi içerisinde ortaya çıkmaktadır (Gerni vd., 2018). Çin'in hem iç hem de diş kayak çekerek yarattığı büyüme modeline karşılık; ABD'nin yetersiz iç kaynaklarına ilaveten çektiği yabancı sermaye daha çok rantsal alanlara yönelmektedir. ABD'de üretimden ziyade tüketimi destekleyici bir model kendini hissettirmektedir. Aşağıdaki şekilde $A B D$ ve Çin'in gayri safi tasarruflarının GSMH'ya oranları verilmiştir. 
Şekil 2: Çin ile ABD’nin Gayri Safi Tasarruflarının GSMH'ya Oranları

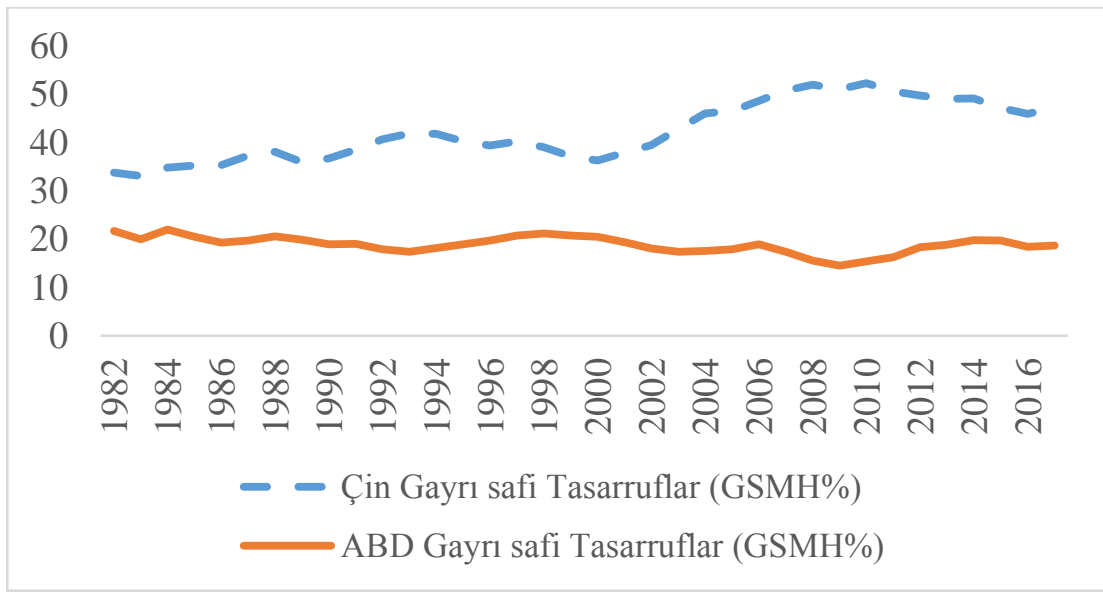

Şekil 2'de ABD'nin tasarruf oranlarının \%20'lerde ve hatta 2000'lerle birlikte \%20'nin de altında seyrettiği görülmektedir. Çin ise ciddi anlamda dış fazla vermesinin yansı sıra ulusal tasarruflar açısından \%40'l rakamların üzerinde bir seyir takip etmektedir. Dolayısıyla ABD'nin bir tür ikiz açıkçı ve Çin'in ise ikiz fazlacı bir yapısının varlığından bahsedilebilir. Yukarıda iki temel noktada Çin'in avantajları adeta süreklilik arz eden bir noktadadır. Buna karşılık Çin'e yönelik eleştirilerin temeli üç ana noktaya toplanmıştır. Bunlardan ilki, DTÖ’ye üye olmasına karşılık ithalatı liberalize etme konusunda yavaş davrandığı ve ihracatın da sübvansiyonlarla teşvik edilmesidir. Bir diğer eleştiri noktası da devlet sahipliğindeki girişimlerin yarattığı monopol avantajıdır ki, bunun da daha çok ticarete konu olmayan finans alanında olması dikkat çekicidir. Ancak, toplam ihracat içerisinde \%50'lerde olan devlet girişimlerinin pay1 halihazırda \%10'un da altına düşmüştür. Aslında fazla dile getirilmeyen eleştiri noktasından üçüncüsü de doğrudan yabancı sermaye yatırımlarıdır ve bu noktada ABD'li yüksek teknoloji firmalarının sırlarını ifşa etmeye ve çoğunluk hisselerini elde tutmaya zorlanmaları iddialarıdır. Bu yönüyle ticaret savaşından ziyade teknoloji savaşından bahsedilmesinin daha uygun olacağı dahi söylenmektedir. Burada da yabancı yatırımın başta kâr olmak üzere elde edeceği yararlar (ucuz arazi, altyap1, vergi istisnaları veya uygun şartlarda krediler) ile maliyetler karşılaştırması yapılabilir. $\mathrm{Bu}$ karşılaştırmalarda da Çin'e yönelik yabancı sermaye kârlılık ve verim oranlarının oldukça yüksek olduğu dikkat çekmektedir (Gros, 2019: 2123). Oysa Çin'e yöneltilen eleştiriler aslında bir tür "merdiveni itme" davranışından başka bir şey olmadığ1 ileri sürülebilir. Ancak, ilk etapta gözlenen bu sıra dişılık, aslında rekabet gücünü elde eden ülkelerin serbestisi, buna karşılık rekabet gücü zayıflayan ülkelerin ise korumacılığa 
yönelimi yeni bir olgu değil; ABD'de ve Almanya'da, Japonya ve G. Kore'de de tarihte siklıkla gözlenen bir durumdur. Diğer bir ifadeyle dezavantajlı konumdayken korumacılık kalkanına bürünme ve avantajlı konuma geçince de serbestiyi savunma adeta olağan kabul edilir bir durum olarak dikkat çekmektedir. Çin'in yüksek teknolojik mal ihracatında sıçrama göstererek adeta önemli bir rakip konumuna gelmesi ve buna bağlı olarak dünyanın bir numaralı ekonomi pozisyonuna geçmesi, kuvvetle muhtemel "bu Çinliler de çok oluyor" sloganıyla özetlenecek düşünceyi akla getirmektedir. İlaveten Çin'in büyümesinin sınırlarına gelerek bir tür orta gelir aşamasında kalması beklenirken, bunun tam aksi yönde büyüme performansı göstermesi ve dünya ekonomisinde en önemli güç olacağına dair tehdit ürkütücü addedilebilir.

Tablo 1: Çin ve ABD’de 1978-2018 Dönemi Kişi Baş1 Ortalama Büyüme Oranları

\begin{tabular}{|cc|ccc|cc|}
\hline $\begin{array}{l}\text { Çin 1978-2018 Kişi } \\
\text { Başı Ort. Büyüme (\%) }\end{array}$ & $\begin{array}{l}\text { Çin 1990-2018 Kişi } \\
\text { Baş1 Ort. Büyüme (\%) }\end{array}$ & $\begin{array}{l}\text { Çin 2009-2018 Kişi } \\
\text { Baş1 Ort. Büyüme (\%) }\end{array}$ \\
\hline \multicolumn{2}{|c|}{8,468} & 8,608 & & 7,409 & \\
\hline $\begin{array}{l}\text { ABD 1978-2018 Kişi } \\
\text { Baş1 Ort. Büyüme }\end{array}$ & ABD 1990-2018 Kişi & ABD 2009-2018 & Kişi \\
\hline \multicolumn{2}{|c|}{ Baş1 Ort. Büyüme } & & Baş1 Ort. Büyüme & \\
\hline
\end{tabular}

Kaynak: Dünya Bankası

Yukarıdaki tablodan da görülebileceği gibi 1978-2018 dönemi kişi baş1 ortalama büyüme oranları ABD'de diğer dönemlerden daha yüksektir. Çin'de ise en yüksek büyüme oranı 1990-2018 döneminde yakalanmıştır. 2009-2018 döneminde ise büyüme oranları hem Çin'de hem de ABD'de düşüş göstermiştir. Ancak genel olarak Çin ekonomisinin ABD ekonomisine göre oldukça yüksek bir büyüme performansı sergilediği görülmektedir. Bu kapsamda aşağıdaki formül yardımıyla Çin ve ABD ekonomilerinde kişi başı gelir düzeylerinin birbirine ne kadarlık bir sürede yaklaşacağı hesaplanmıştır (Kaynak, 2011).

$$
\begin{gathered}
Y_{G \ddot{U}}\left(1+r_{G \ddot{U}}\right)^{n}=Y_{A G \ddot{U}}\left(1+r_{A G \ddot{U}}\right)^{n} \\
\frac{\log \frac{Y_{G \ddot{U}}}{Y_{A G \ddot{U}}}}{\log \left(1+r_{A G \ddot{U}}\right)-\log \left(1+r_{g \ddot{u}}\right)}
\end{gathered}
$$

Çin ve ABD ekonomilerinin 1978-2018 dönemi büyüme performanslarını sürdürmeleri halinde yapılan hesaplamalara göre 29 yıl sonra Çin' deki kişi başına düşen gelirin ABD'dekini yakalaması beklenmektedir. Çin ve ABD ekonomilerinin 1990-2018 dönemi büyüme performans1 söz konusu olduğunda bu oran 27,5 yıla düşmekte, 2009-2018 dönemi büyüme 
performansının gerçekleşmesi halinde ise 30,4 yıl sonra Çin'deki kişi başına düşen gelirin ABD'dekini yakalaması söz konusu olacaktır.

Tablo 2: Çin ve ABD'de 1978-2018 Dönemi Kişi Başına Gelir Düzeyleri

\begin{tabular}{|l|c|c|c|}
\hline Y1l & Çin KBG $(\$)$ & ABD KBG $(\$)$ & ABD/Çin Fark \\
\hline 1978 & 156,396 & 10564,948 & 67,552 \\
\hline 1990 & 317,885 & 23888,600 & 75,149 \\
\hline 2009 & 3832,236 & 47099,980 & 12,290 \\
\hline 2018 & 9770,847 & 62794,586 & 6,427 \\
\hline
\end{tabular}

Kaynak: Dünya Bankası verilerinden derlenmiştir.

Yukarıdaki tabloda ise Çin ve ABD ekonomilerinde 1978, 1990, 2009 ve 2018 yıllarında kişi başına düşen gelir düzeyi ve farklılıkları görülmektedir. 1978 yılında bir ABD vatandaşının gelirinin bir Çin vatandaşından 67 kat daha fazla olduğu görülmektedir. Bu fark giderek azalarak 2018 yılında 6,4 kata kadar düşmüştür. Çin ekonomisindeki hızlı gelişimin devam etmesi halinde ise bu farkın 27-30 yıl arasında bir sürede kapanması beklenmektedir.

\section{Ticaret Savaşının Yansımaları Üzerine Literatür İncelemesi}

Ticaret savaşı olgusunda ortaya çıkan etkilerin incelenmesine yönelik olarak Nash optimal tarife hesaplaması yapilabilmektedir. Buna göre modeller şu hususları dikkate alır: (i) modellerin boyutsallığı: bölge sayısı, üretim sektörü ve faktörler, (ii) kullanılan teorik ticaret modelinin altında yatanlar Heckscher-Ohlin-Samuelson modeli Chipman (1969), Krugman (1980), Eaton ve Kortum (2002) veya Melitz (2003), (iii) kullanılan sayısal genel denge modeli: Heckscher-Ohlin-Samuelson, hesaplamalı genel denge ve/veya diğer sayısal genel denge modeller (örneğin yapısal ağırlık, yeni nicel ticaret modelleri gibi), (iv) modellerin spesifik karakterleri: piyasa yapısı, üretim ve tüketim teknolojileri, orta düzey bağlar ve faktör hareketliliği, (v) makroekonomik kapanışlar: ticaret dengesi, kamu dengesi ve yatırım-tasarruf kararları, (vi) zaman boyutu: faktör donatımlarında/birikiminde değişiklik olan veya olmayan statik veya dinamik modeller, (vii) sayısal simülasyon içeriği: analiz edilen ülkeler/bölgeler ve zaman dilimi, (viii) kullanılan spesifik ticari esneklikler: varsayılan değerlerin kalibre edilmiş, tahmin edilmiş ve/veya kullanılmış olup olmaması, (ix) kullanılan temel ekonomik veriler: kurum veya kuruluşlarca ya da araştırmacılarca oluşturulması, (x) kullanılan model özellikleri ve parametre değerleri - özellikle ticaret esnekliği değerleri - Nash optimal tarife değeri aralığ \%5 ila \%10 arasında değişmekte, (xii) tahmini refah etkileri de geniş ölçüde değişmekte (Bekkers vd., 2019: 13). 
Çin ve ABD arasındaki ticari gerginliğin yayılma etkileri noktasında ASEAN ülkelerinden Malezya üzerine yapılan çalışma konuya eğilen çalışmalara örnek teşkil etmektedir. Malezya gibi dışa açıklık derecesi ve bunun içerisinde Çin ile ekonomik ilişkileri yüksek derecede ilişkili olan ekonomilerde bu gerginliğin doğuracağı etkiler özellikle Çin ile ABD'nin ihracatta payının yüksekliğinden dolayı daha derinden hissedilmesi beklenmektedir. Şöyle ki, 2017 yılı itibarıyla Çin'e 67.229 milyon dolar (toplamdaki payı \%16.4) ve ABD'ye 36.350 milyon dolar (toplamdaki payı \%8.9) ihracatı olan Malezya'nın dışa açıklık derecesi de \%131.1'dir ve bu yönüyle kuvvetli bir re-export yapan ülke konumundadır (Yean vd., 2019: 1). Dolayısıyla tüm dünyaya yayılması kuvvetle muhtemel bir resesyonist süreçten bahsedilebilir $\mathrm{ki}$, dünya hasılasının \%10'unu oluşturan Çin gibi bir ekonomide yayılma etkileri daha güçlü bir şekilde kendini hissettirecektir. Buna göre IMF tarafından yapılan simülasyonda ABD ve Çin'in GYSYİH değerlerinin sırasıyla $\% 0.9$ ve $\% 0.6$ düşeceğini ve uzun dönemde de dünya GSYİH değerinin $\% 0.4$ azalacağına işaret etmiştir (Chong ve Li, 2019: 21). Ticari kısitlamaya maruz kalan ülkede gelir ve istihdamda daralma ile buna bağlı olarak dolaylı bir şekilde ortaya çıkan tüketim azalışı etkileri gözükür. Buna karşılık nihai mallarda kısıtlamayı uygulayan ülke tüketicileri için de ucuz ve kaliteli mal tüketme olanağ1 ortadan kaldırılmış olmaktadır (Chong ve Li, 2019: 6). Şüphesiz her iki ülke açısından refah azalışları söz konusu olmaktadır. Ayrıca Çin'in ABD'ye ihracatının emek-yoğun endüstriler kapsamında olduğu dikkate alındığında, ticari kısıtlamaların işgücü üzerine etkilerinin daha yoğun olması beklenebilir. Buna ilaveten cari fazlayı en güçlü şekilde verilen ve en fazla yabancı sermaye çekilen ABD'nin uygulamaları sonucu rezerv varlıklarda da azalış olacağı düşünülebilir (Chong ve Li, 2019: 20).

Yean vd. (2019: 15) tarafından yapılan çalışmada ticaret savaşının Çin ve Malezya üzerine etkileri araştırılmıştır. Çalışmadan elde edilen buğularda Çin üzerine yapılan kısıtlamaların ikame etkileri aratarak Malezya ihracatını olumlulaştırdığı tespit edilmiştir. Özellikle Malezya'nın ABD'ye ihracatının yurtiçi üretim menşeili ihracattan ziyade, re-export etkileri yoluyla gerçekleştiği gözlenirken, araştırmanın yapıldığ 2018 yılı itibarıyla Çin ihracatında azalma olmadığı gözlenmiştir. Diğer taraftan ticaret savaşının derinleşmesi halinde Çin'den Malezya'ya doğru doğrudan yabancı sermaye yatırımlarında bir artışın olabileceği öngörüsü de yapılmıştır. Amiti vd. (2019) tarafından yapılan çalışmada tarife uygulamalarının etkileri regresyon tahminleri ile ortaya konulmaya çalışılmıştır. 2017:01-2017:12 arası dönem için logaritmik değerler ile yapılan tahminlerde yurtiçi tüketiciler ile ithalatçıların reel gelirlerinde azalmaya yol açtığı tespit edilmiştir. Ayrıca tarifelerin uluslararası arz incirinde dramatik azalışlara da yol açtığı belirlenirken; ithal ikameci 
sektörlerde üretim yapanların da fiyatları artırarak tüketici artığını elde ettikleri gözlenmiştir (Amiti vd. (2019). Hesaplanabilir Genel Denge (Computable General Equilibrium-CGE) modelleri yardımıla ticaret savaşlarının etkileri üzerine farklı senaryolar türetilmektedir. Bollen ve Rojan-Romagosa (2018) tarafından yapılan çalışmada beş farklı senaryo türetilmiştir: Birincisi, ABD'nin tek taraflı çelik ve alüminyum tarifeleri; ikincisi, $\mathrm{ABD}$ çelik ve alüminyum tarifeleri üzerine misilleme; üçüncüsü ABD-Çin ticaret yaptırımları; dördüncüsü, $\mathrm{ABD}$ motorlu kara taşıtlarına uygulanan tarifeler; beşincisi, ticari savaşın derinleşmesi. İlk iki senaryoda küresel etkiler sınırlı bulunmuş iken, $\mathrm{ABD}$ ve onun NAFTA ortaklarının negatif etkileneceği tespit edilmiştir. Üçüncü senaryoda Çin'in GSYIHH değerinde \%1.2'lik bir kayıp ve ABD GSYİH değerinde ise \%0.3'lük bir olumsuz etkilenmenin olacağ 1 ileri sürülmüştür. $B u$ senaryoda $A B$ ve OECD ülkelerinin olumlu yönde etkilenmeler yaşayacağı belirtilmiştir. Dördüncü senaryoda $\mathrm{AB}$ ülkeleri diğer taşıma ekipman sektöründen kazançlı olacak şekilde etkilenecektir. Beşinci senaryoda ise ABD ile diğer ülkeler arasında tek tip hizmet tarife artışı uygulandığından tüm ülkeler tarife nedeniyle kayıpta olacaklardır (Bollen ve Rojan-Romagosa, 2018).

Çok ülkeli genel denge modelini kullanan Guo vd. (2018) ABD'nin Çin üzerine tarifeleri $\% 45$ yükseltmesi halinde dünya ticareti üzerine ters etkilerinin olacağı belirlenmiştir. Ticaret açısından Çin'in küçük ülkelere doğru eksen kayması yapabileceği ve buna karşılık ABD'nin daha fazla üretim yapmak zorunda olacağı belirlemesi yapılmıştır. Reel ücretlere de Çin'in benzeri misillemede bulunması halinde çok zayıf etkilerinin bulunacağı ve bu noktada ticaret hadleri kazançlarından dolayı etkilenme derecesinin düşük düzeyde kalacağı tespit edilmiştir. Küçük dışa açık ülkelerin kazanımlarının olacağı ileri sürülürken, bu kazanımlar açısından Malezya'nın \%1.4 ve Singapur'un da \%2.6 refah kazanımının (reel ücretlerle ölçülen) olacağı ileri sürülmüştür (Guo vd., 2018). Charbonneau ve Landry (2018) tarafindan yapılan çalışmada ABD ve Çin arasındaki tarife savaşının Caliendo ve Parro (2015)'in Ricadocu modeli kullanılarak uzun dönemde ticaret esneklikleri tahmin edilmiştir. Elde edilen bulgularda sektörler ve ülkeler arasındaki teknolojideki farklılıkların rekabet avantajı ve ticareti etkileyeceği görülmüştür. Ayrıca girdi-çıktı tablolarında da farklı kalkınma aşamalarını içeren kaynaklar ve teknoloji açısından farklılıkların olduğu ülkeler arasındaki ticaretin ortaya çıktığı tespit edilmiştir. Bulgularda tarifelerin ticaret akımlarında ve kaynak dağılımında değişime yol açtığı ve ilaveten uzun dönemde toplam fiyatları ve üretim seviyesini etkilediği tespit edilmiş̧ir (Charbonneau ve Landry, 2018). 
Cali (2018) tarafindan yapılan çalışmada da ABD'nin Çin'den yaptığ 1 ithalatın ABD ithalat talep esnekliğine bağlı olarak 68.6 milyar dolar düşeceğini ortaya koymuştur. Çin'e uygulanan tarifeler sonucu en fazla zarar görebilecek ülkeler olarak GSYİH daralması şeklinde Tayvan ve Malezya'nın olacağ tahmin edilmiştir (Cali, 2018). Abiad vd. (2018) ise Asya Kalkınma Bankası'nın çok bölgeli girdi-çıktı tablolarını kullanmak suretiyle gelişmekte olan Asya üzerine etkilerini incelemiştir. Buradan hareketle üç senaryo türetilmiştir: mevcut durum, ticaret savaşının tırmanışı ve daha kötü durum senaryosu. Çalışma tarifelerden etkilenen mallar üzerine doğrudan etkileri tahmin etmiş ve bireysel ülke etkileri açısından GSYIH, istihdam ve ihracat üzerine dolaylı etkileri tahmin etmek için girdi-çıktı analizlerini kullanmıştır. Malezya için sonuçlarda hem GSYIH hem de ihracat üzerine üç senaryoda da makul pozitif kazançların olacağı ortaya konulmuştur. Aizuddin vd. (2018) de yaptığı çalışmada Malezya'nın ABD piyasasına en fazla mal satan ülkelerden olması nedeniyle 970 milyon dolarlık bir kazanım elde edeceğini ortaya koymuştur. Kısıtlı literatür ticari gerilimin Çin ile Çin'in ticari ilişkiler içerisinde bulunduğu başta Malezya olmak üzere ticaret, GSYIH ve istihdam gibi bir takım göstergelerin performansı üzerine etkilerini araştırmıştır. Araştırmaların bir kısmı olumsuz senaryolarda kısmı daralma etkilerinin olacağı kabul edilmekle birlikte, alternatif politika üretmekle bu etkilerin düşük düzeyde kalacağına temas ederken, bir kısım araştırmalarda da farklı açılımlar ve politika uygulamalarının pozitif etkiler dahi yaratabileceğini ortaya koymuştur.

\section{Ticarette Kur ve Rekabet Gücü Etkileri Araştırması}

Çalışmada 1995-2018 dönemi Çin ve ABD dış ticareti inceleme konusu yapılmış ve Çin'in ABD ile olan diş ticaretinde rekabet gücünü artırarak mı, yoksa kur avantajını kullanarak mı ABD karşısında dış ticaret fazlası verdiği belirlenmeye çalışılmıştır. Bu kapsamda önce ABD-Çin dış ticaret verileri kullanılarak Çin'in hangi mallarda rekabet gücünün olduğu tespit edilmiş ve daha sonra elde edilen rekabet gücü katsayıları ile Çin'in ihracatında büyük pay sahibi olan mal grupları için zaman serisi analizleri yapılmıştır. Bu kapsamda ilgili mal gruplarının toplam ihracat içindeki payı bağımlı değişken, Balassa endeksinden elde edilen rekabet gücü katsayıları, döviz kuru (Dolar/Yuan) ve kontrol değişken olarak da sabit sermaye yatırımlarının GSYİH'ya oranı bağımsız değişkenler olarak kullanılmıştır. Veriler UNCTAT (United Nations Conference on Trade and Development) ve Worldbank (Dünya Bankası)'dan elde edilmiştir. Rekabet gücü analiz edilirken, Standart Uluslararası Ticaret Sinıflaması sistemi (SITC) sisteminde en yüksek toplulaştırma düzeyi bir basamaklı ayrım esas alınmıştır. Standart Uluslararası Ticaret Sınıflaması sistemi 
(SITC) inde mal grupları on kategori olarak tasnif edilmektedir. $\mathrm{Bu}$ kategoriler; 0: canlı hayvanlar ve gıda maddeleri, 1: içecek ve tütün 2: akaryakıt hariç yenilmeyen hammaddeler, 3: mineral yakıtlar, yağlar ve alkali ürünler, 4: hayvansal, bitkisel katı ve sıvı yağlar, mumlar, 5: başka yerde belirtilmeyen kimyasal sanayi ürünleri, 6: başlıca sınıflara ayrılan işlenmiş mallar, 7: makine ve taşıt araçları, 8: çeşitli mamul eşya, 9: STIC'de sınıflandırılmamış eşyalar olarak tasnif edilmiştir.

Çalışmada kullanılan Açıklanmış Karşılaştırmalı Üstünlükler (AKÜ) [Revealed Comparative Advantage - RCA] yaklaşımı, rekabet gücünün tespitinde sıkça faydalanılan bir yöntemdir. Balassa'nın (1965) AKÜ yaklaşımı, bir ülkenin belli bir mal ya da endüstri ticaretinde karşılaştırmalı üstünlüğünü ölçmek için, bu mal ya da endüstrinin toplam dünya ihracatındaki payının, ülkenin toplam dünya ihracatındaki payına oranını veren bir indeks oluşturmuştur. Elde edilen sonuçlar ülkenin karşılaştırmalı üstünlüğe sahip olup olmadığının göstermektedir (Çakmak, 2005). Balassa'nın (1965) geliştirdiği Açıklanmış Karşılaştırmalı Üstünlükler (AKÜ) yöntemi ile ülkelerin dış ticaretteki rekabet gücü ölçülmektedir. AKÜ, dış rekabet gücü ölçüm yöntemi, üretim faaliyetlerinin yanı sıra fiyat dışı faktörlerin de analize dahil edilmesini gerektirir. i ülkesinin $\mathrm{j}$ malına (veya mal grubuna) ait AKÜ endeksi, genellikle malın ülke toplam ihracatı içindeki payının dünya toplam ticareti (veya bölge toplam ticareti) içindeki payına oranlanması ile ölçülmektedir (Yurttançıkmaz vd., 2014). Balassa'nın oluşturduğu formül şu şekildedir:

$\mathrm{AKÜ} 1=\frac{X_{i j} / X_{i t}}{X_{w j} / X_{w t}}$

Formülde, 'i' rekabeti yapılan mal, 'j' rekabet yapan ülke, ' $w$ ' toplam dünya ihracatı, ' $x$ ' ise ihracatı temsil etmektedir. Endeks ölçümü neticesinde sonuç 1'den büyükse, ülkenin karşılaştırmalı üstünlüğe sahip olduğu; endeks değeri 1'den küçükse, karşılaştırmalı dezavantajı olduğu anlaşılmaktadır. Bir diğer Balassa formülü de şu şekildedir:

$\mathrm{AKÜ}_{2}=\ln \left[\frac{X_{i j} / X_{i t}}{M_{i j} / M_{i t}}\right]$

Xij : i ülkesinin ' $\mathrm{j}$ ' ürünündeki ihracatı, Xit : i ülkesinin toplam ihracatı, Mij : i ülkesinin ' $\mathrm{j}$ ' ürünündeki ithalatı, Mit : i ülkesinin toplam ithalatı. Elde edilen AKÜ değeri: $-0.5<$ AKÜ $<0.5$ ise ilgili malda karşılaştırmalı üstünlük sinırlıdır, AKÜ<-0.5 ise karşılaştırmalı üstünlük düşük, AKÜ $>0.5$ ise ilgili malda ülkenin karşılaştırmalı üstünlüğü yüksektir (Altıntaş ve Akpolat, 2013). 
Şekil 3: Çin'in 6, 7 ve 8 nolu Mal Gruplarının Toplam İhracatındaki Payı

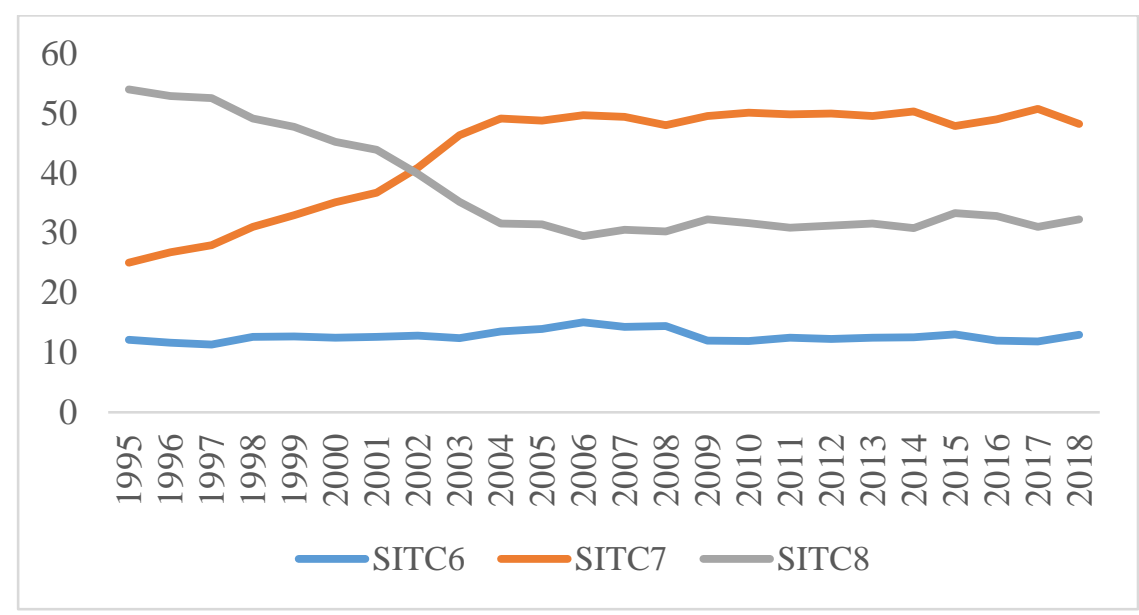

Çin ile ABD'nin dış ticaretinin analiz edildiği bu çalışmada rekabet gücünün bulunmasında $\mathrm{AKÜ2}$ formülünden yararlanılarak rekabet gücü hesaplanmıştır. Çin'in ABD'ye olan ihracatında en önemli pay başlıca sınıflara ayrılan işlenmiş mallar (SITC-6), makine ve taşıt araçları (SITC7) ve çeşitli mamul eşya (SITC-8) olduğu görülmektedir. Bu üç mal grubu Çin'in ABD'ye olan ihracatının yaklaşık \%90'lık bölümünü oluşturmaktadır. Zaten aşağıdaki tabloda da görülebileceği gibi Çin'in rekabet gücünün yüksek olduğu mal grupları da bu üç gruptur. AKÜ2 endeksine göre elde edilen sonuçların 0.5 'den büyük ise ülke o malda karşılaştırmalı olarak üstünlüğe sahiptir. Bu kapsamda Çin'in ABD ile olan dış ticaretinde çeşitli mamul eşya (SITC-8) grubunda en yüksek rekabet gücüne sahiptir. Bunu sırası ile başlıca sınıflara ayrılan işlenmiş mallar (SITC-6) ile makine ve taşıt araçları (SITC-7) mal grupları takip etmektedir. 
Şekil 4: Çin'in ABD'ye Karşı 6, 7 ve 8 nolu Mal Gruplarında Rekabet Gücü

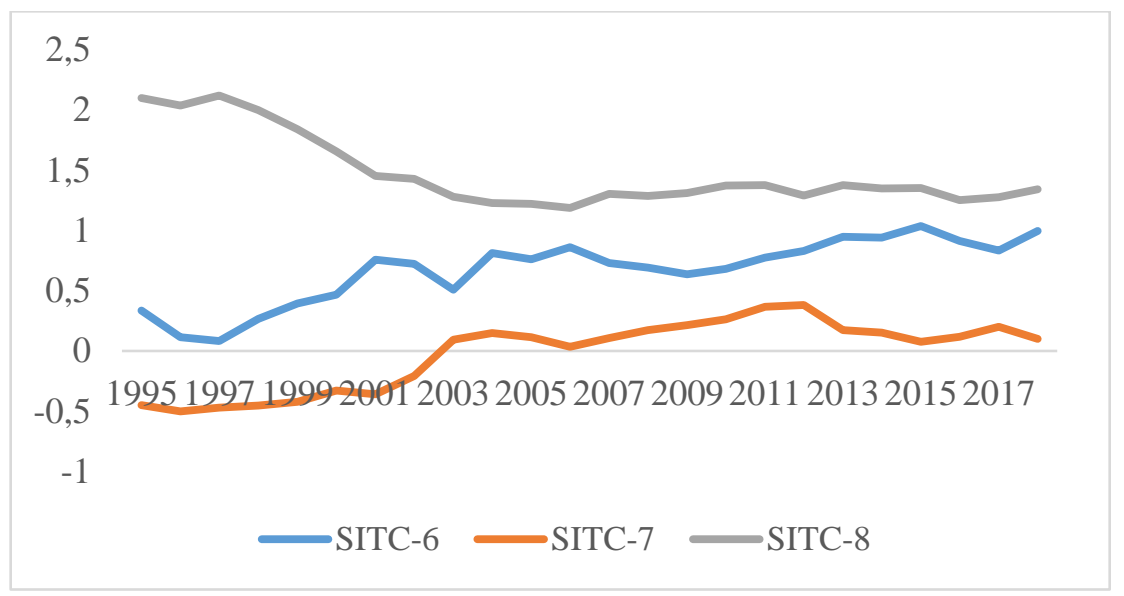

Yukarıdaki grafikten de görülebileceği gibi başlıca sınıflara ayrılan işlenmiş mallar (SITC-6), makine ve taşıt araçları (SITC-7) ve çeşitli mamul eşya (SITC-8) mal gruplarında rekabet gücü oldukça yüksektir. Başlıca sınıflara ayrılan işlenmiş mallar (SITC-6) ve taşıt araçları (SITC7) alanında rekabet gücünün artmakta olduğu görülürken, çeşitli mamul eşya (SITC-8) mal grubunda rekabet gücünün azaldığı ancak halen yüksek düzeyli olduğu görülmektedir. Elde edilen rekabet gücü düzeylerinden sonra söz konusu üç mal grubunda (başlıca sınıflara ayrılan işlenmiş mallar (SITC-6), makine ve taşıt araçları (SITC-7) ve çeşitli mamul eşya (SITC8) ihracat düzeyi üzerinde hangi değişkenlerin etki ettiğinin tespitine çalışılmıştır. Bu kapsamda elde edilen rekabet gücü değerleri (RG), döviz kuru (DK) ve sabit sermaye birikiminin (SSB) GSYİH'ya oranı bağımsız değişken olarak alınarak bağımlı değişen olan yukarıdaki seçili mal gruplarının toplam ihracata oranı üzerinde etkileri incelenmiştir.

$$
\begin{aligned}
& \text { SITC6 }=b_{0}+b_{1} \text { RG6 }+b_{2} \text { DK }+b_{3} \text { GCF (3) } \\
& \text { SITC7 }=b_{0}+b_{1} \text { RG7 }+b_{2} \text { DK }+b_{3} \text { GCF (4) } \\
& \text { SITC8 }=b_{0}+b_{1} \text { RG8 }+b_{2} \text { DK }+b_{3} \text { GCF (5) }
\end{aligned}
$$

Yukarıdaki ekonometrik modellerde; SITC6 başlıca sinıflara ayrılan işlenmiş malları; SITC7 makine ve taşıt araçlarını; SITC8 çeşitli mamul eşyayı temsil etmektedir. Değişkenlerin önce birim kök analizleri yapılmıştır. $\mathrm{H}_{0}$ hipotezi serilerin durağan olmadığını ifade etmektedir. Çalışmada kullanılan tüm değişkenler birinci farktan durağan çıkmışlardır. Modelde kullanılan değişkenlere ait korelasyon katsayıları aşağıdaki tabloda verilmiştir. 
Tablo 3: Korelasyon Tablosu

\begin{tabular}{|l|c|c|c|c|c|}
\hline & SITC6 & & SITC7 & & SITC8 \\
\hline SITC6 & 1 & SITC7 & 1 & SITC8 & 1 \\
\hline R6 & 0.387 & R7 & 0.953 & R8 & 0.952 \\
\hline DK & 0.105 & DK & -0.687 & DK & 0.666 \\
\hline GCF & -0.012 & GCF & 0.787 & GCF & -0.774 \\
\hline
\end{tabular}

Korelasyon katsayıları incelendiğinde, SITC6 üzerinde rekabet gücü düzeyinin ve döviz kurunun pozitif yönlü etkileri olduğu görülmüştür. SITC7 üzerinde rekabet gücü düzeyinin pozitif ve döviz kurunun negatif yönlü etkileri olduğu görülmüştür. SITC8 üzerinde rekabet gücü düzeyinin ve döviz kurunun pozitif yönlü etkileri olduğu görülmüştür.

Tablo 4: Düzey ve Birinci Fark Değerleri İçin (ADF) Birim Kök Testi Sonuçları

\begin{tabular}{|c|c|c|c|c|}
\hline \multirow[t]{2}{*}{ Değişkenler } & \multicolumn{2}{|c|}{ Düzey Değerleri } & \multicolumn{2}{|c|}{ Birinci Fark Değerleri } \\
\hline & Değer & Olasılık & Değer & Olasılık \\
\hline SITC-6 & -2.24 & 0.19 & -3.30 & 0.02 \\
\hline RG6 & -1.28 & 0.61 & -5.51 & 0.00 \\
\hline SITC-7 & -2.34 & 0.16 & -3.37 & 0.02 \\
\hline RG7 & -1.93 & 0.31 & -3.43 & 0.02 \\
\hline SITC-8 & -2.43 & 0.14 & -3.01 & 0.05 \\
\hline RG8 & -2.20 & 0.21 & -3.34 & 0.02 \\
\hline DK & -1.03 & 0.72 & -3.19 & 0.03 \\
\hline SSB & -1.51 & 0.50 & & \\
\hline & \multicolumn{2}{|c|}{$\begin{array}{l}\text { Kritik Değerler: } 1 \% \text { level :- } \\
3.76,5 \% \text { level : }-2.99,10 \% \\
\text { level : }-2.64\end{array}$} & \multicolumn{2}{|c|}{$\begin{array}{l}\text { Kritik Değerler: } 1 \% \text { level : } \\
3.78,5 \% \text { level : }-3.01,10 \% \\
\text { level : }-2.64\end{array}$} \\
\hline
\end{tabular}

$\mathrm{H}_{0}$ hipotezinin reddi serilerin birim kök içermediğini ifade eder. Tüm değişkenlerin birinci dereceden farkları alındıktan sonra, durağan olduğu görülmüsstür. Seriler birinci farktan durağan olması nedeniyle analizlerde eş-bütünleşme testine gidilmesi uygun bulunmuştur. Dolayısıyla çalışmada Çin'in toplam ihracatının yaklaşık \%90'lık kısmını oluşturan; başlıca sınıflara ayrılan işlenmiş mallar (SITC-6), makine ve taşıt araçları (SITC-7) ve çeşitli mamul eşya (SITC-8) mal grupları için ayrı ayrı üç model kurulmuş ve analiz edilmiştir. Eş-bütünleşme analiz sonuçları aşağıdaki tabloda verilmiştir. 
Tablo 5: Eş-bütünleşme Analiz Sonuçları

\begin{tabular}{|c|c|c|c|c|c|c|c|c|c|}
\hline \multicolumn{3}{|c|}{$\begin{array}{l}\text { Seriler: SITC6 R6 DK GCF } \\
\text { Gecikme uzunluğu: } 1-3\end{array}$} & \multicolumn{3}{|c|}{$\begin{array}{l}\text { Seriler: SITC7 R7 DK } \\
\text { GCF Gecikme uzunluğu: } \\
1-3\end{array}$} & \multicolumn{3}{|c|}{$\begin{array}{l}\text { Seriler: SITC8 R8 DK } \\
\text { GCF Gecikme uzunluğu: } \\
1-3\end{array}$} & \multirow[b]{2}{*}{$0.05 \mathrm{Kr}$. } \\
\hline H & n & $\dot{\mathbf{I} z}$ & $\mathbf{H}_{\mathbf{0}}$ & Eigen & $\dot{\mathbf{I} z}$ & $\mathbf{H}_{\mathbf{0}}$ & Eigen & $\dot{\mathbf{I} z}$ & \\
\hline & & & & & 144.027 & & 40 & 74.8 & \\
\hline & & & $*$ & 56 & 5 & & & & \\
\hline & & & & 0.481 & 14.238 & & 0.549 & 15.949 & \\
\hline & & $\dot{\mathbf{I} z}$ & & Eigen & $\dot{\mathbf{I} z}$ & & Eigen & $\dot{\mathbf{I} z}$ & \\
\hline & & & & & 89.561 & & & 36.72 & \\
\hline & & & & 0.866 & 40.227 & & & & \\
\hline $2 *$ & 0.511 & 14.307 & At most $2 *$ & 0.481 & 13.137 & At most $2 *$ & 0.549 & 15.933 & \\
\hline \multicolumn{3}{|c|}{$\begin{array}{l}\text { İz istatistiği testi ve Max- } \\
\text { eigenvalue testi } 0.05 \\
\text { düzeyinde } 3 \text { kointegre } \\
\text { denkleminin } \\
\text { kurulabileceğini } \\
\text { göstermektedir.* }\end{array}$} & \multicolumn{3}{|c|}{$\begin{array}{l}\text { İz istatistiği testi ve Max- } \\
\text { eigenvalue testi } 0.05 \\
\text { düzeyinde } 3 \text { kointegre } \\
\text { denkleminin } \\
\text { kurulabileceğini } \\
\text { göstermektedir.* }\end{array}$} & \multicolumn{3}{|c|}{$\begin{array}{l}\text { İz istatistiği testi ve Max- } \\
\text { eigenvalue testi } 0.05 \\
\text { düzeyinde } 3 \text { kointegre } \\
\text { denkleminin } \\
\text { kurulabileceğini } \\
\text { göstermektedir.* }\end{array}$} & $\begin{array}{l}.05 \\
\text { üzeyinde } \\
0\end{array}$ \\
\hline
\end{tabular}

Elde edilen bulgular her üç modelde de en az üç eş-bütünleşik vektör olduğunu göstermektedir. Eş-bütünleşme testinden elde edilen normalizasyon denklemleri şu şekildedir:

SITC $6=4.88 \mathrm{R} 6+1.37 \mathrm{DK}+0.02 \mathrm{SSB}$

SITC $7=37.07 \mathrm{R} 7+5.49 \mathrm{DK}+0.15 \mathrm{SSB}$

SITC $7=19.86 \mathrm{R} 7+1.56 \mathrm{DK}+0.11 \mathrm{SSB}$

Yani rekabet gücündeki artışlar SITC6 mal grubunun toplam ihracat içindeki payını pozitif yönlü etkilemektedir. Benzer şekilde döviz kurlarındaki artışlarda SITC6 mal grubunun toplam ihracattaki payı üzerinde pozitif etkilidir. Rekabet gücündeki artışlar, döviz kurunun değer kazanması ve sabit sermaye birikimindeki artışlar SITC7 mal grubunun toplam ihracat içindeki payını pozitif yönlü etkilemektedir. SITC8 mal grubunun toplam ihracat içindeki payı üzerinde rekabet gücündeki artışlar, döviz kurunun değer kazanması ve sabit sermaye birikimindeki artışların pozitif yönlü etkisi bulunmaktadır. Analize koşulan (3), (4) ve (5) nolu modellere ilişkin nedensellik test sonuçları da Tablo 6'da verilmiştir. 
Tablo 6: Granger Nedensellik Testi Sonuçları

\begin{tabular}{|l|c|c|c|}
\hline Sıfır Hipotezi & $\begin{array}{c}\text { F- } \\
\text { İstatistik }\end{array}$ & $\begin{array}{c}\text { Olasılık } \\
\text { Değeri }\end{array}$ & Sonuç \\
\hline DK, SITC6'nın Granger nedeni değildir & 43.47 & 0.02 & $\mathrm{H}_{0}$ red \\
\hline R6, SSB'nin Granger nedeni değildir & 3.480 & 0.04 & $\mathrm{H}_{0}$ red \\
\hline SSB, DK'nın Granger nedeni değildir & 3.59 & 0.07 & $\mathrm{H}_{0}$ red \\
\hline SITC7, DK Granger nedeni değildir & 5.46 & 0.03 & $\mathrm{H}_{0}$ red \\
\hline SITC7, R7'nin Granger nedeni değildir & 5.82 & 0.02 & $\mathrm{H}_{0}$ red \\
\hline SITC7, SSB'nin Granger nedeni değildir & 9.53 & 0.01 & $\mathrm{H}_{0}$ red \\
\hline R7, SSB'nin Granger nedeni değildir & 13.34 & 0.01 & $\mathrm{H}_{0}$ red \\
\hline R7, DK'nın Granger nedeni değildir & 8.18 & 0.01 & $\mathrm{H}_{0}$ red \\
\hline R8, SITC8'in Granger nedeni değildir & 12.50 & 0.00 & $\mathrm{H}_{0}$ red \\
\hline R8, SSB'nin Granger nedeni değildir & 10.72 & 0.00 & $\mathrm{H}_{0}$ red \\
\hline SITC8, DK'nın Granger nedeni değildir & 6.76 & 0.02 & $\mathrm{H}_{0}$ red \\
\hline SITC8, SSB'nin Granger nedeni değildir & 10.23 & 0.00 & $\mathrm{H}_{0}$ red \\
\hline
\end{tabular}

Granger nedensellik analizi sonuçlarına göre SITC7'nin döviz kuru, rekabet gücü ve sabit sermaye birikimi ile nedensellik ilişkisi bulunmaktadır. Ayrıca rekabet gücünün (R7) sabit sermaye birikimi ve döviz kuru ile nedensellik ilişkisi bulunduğu görülmektedir. Granger nedensellik analizi sonuçlarına göre rekabet gücünün (R8) çeşitli mamul eşya (SITC8) ile sabit sermaye birikimi ile nedensellik ilişkisi bulunduğu görülmektedir. SITC8'in ise döviz kuru ve sabit sermaye birikimi ile nedensellik ilişkisi bulunmaktadır.

\section{Sonuç}

ABD'nin Çin'den yaptığ 1 ithalat üzerindeki vergileri artırmak istemesi üzerine başlayan ticaret savaşı dünya ekonomisi üzerinde serbest ticaret tartışmalarını yeniden alevlendirmiştir. Korumacılığın korumacılığ 1 getireceği ve bunun ise dünya refahı üzerinde olumsuz yansımalarının olacağı muhakkaktır. Çalışmanın ekonometrik bulgularından hareketle, Çin ile ABD arasındaki ticaret savaşı olgusunda ABD'nin iddia ettiği gibi düşük kur politikasının mı, yoksa Çin'in iddia ettiği gibi kendi rekabet gücündeki gelişmelerin mi ABD'yi ürküttüğü sorusuna cevap aranmıştır. $\mathrm{Bu}$ sorunun cevabında, ya dünya liberalizm savunucusu ABD'nin haklılığını ve dolayısıyla Çin'e karşı dış açık vermesinin haksız kur politikalarından kaynaklandığı söylenebilecektir. Buna karşı1lı Çin'in rekabet gücündeki yükselişlerin ve buna bağlı olarak dış fazla vermesi durumunun ortaya çıkması halinde de ABD'nin anti-liberal tutum içerisinde bulunduğu ve dolayısıyla merdiveni itme davranışı sergilediği söylenebilir ki, bu noktada Çin'in yükselişi ABD tarafından bir tehdit olarak algılanır olduğu söylenebilir. Bu kapsamda yapılan analizlerde 
Çin'in dış ticareti üzerinde rekabet gücünün, döviz kurunun ve sabit sermaye birikiminin ihracat üzerindeki etkileri incelenmiştir. Analizlerde özellikle Çin'in ABD'ye olan ihracatının \%90'lık kısmını oluşturan çeşitli mamul eşya, başlıca sınıflara ayrılan işlenmiş mallar ve makine ile taşıt araçları sektörleri incelenmiştir. Elde edilen analiz sonuçlarına göre Çin'in ABD ile olan diş ticaretinde çeşitli mamul eşya (SITC-8) grubunda en yüksek rekabet gücüne sahiptir. Bunu sırasıyla, başlıca sınıflara ayrılan işlenmiş mallar (SITC-6), makine ve taşıt araçları (SITC-7) mal grupları takip etmektedir. Buradan elde edilen sonuçlarla zaman serisi analizlerine geçilmiştir. Elde edilen bulgular Çin'in ilgili sektörlerdeki rekabet gücündeki artışların ilgili sektörlerin ihracatlarını olumlu yönde etkilediğini göstermiştir. Döviz kurlarındaki ve sabit sermaye birikimindeki artışlar da ihracat üzerinde olumlu etki yapmaktadır. Bu açıdan değerlendirildiğinde, Çin'in sadece döviz kuruna dayalı bir rekabet gücünün varlığından bahsedilemeyeceği; sermaye birikimi ve rekabet gücündeki iyileşmelerin ihracatını artırmada daha önemli rol oynadığı sonucuna ulaşılmıştır. Dolayısıyla ABD yönetiminin ekonomi ve dış ilişkilerde uyguladığı politikaların yansıması olarak Çin ile olan dış ticaretinde büyük açık verilmesinin büyük sorun olarak algılandığı ve bunu çözmek için Çin üzerinde çeşitli ekonomik baskılara başladığı söylenebilir. $\mathrm{Bu}$ yönüyle yükselen güç konumundaki Çin'i frenleme gayretinin varlığından söz edilebilir.

\section{Kaynaklar}

Abiad, A., Baris, K. Bernabe, J.A., Bertulfo, R., Paul Neilmer Feliciano, Mahinthan J. and Mercer-Blackman V. (2018), The Impact of Trade Conflict on Developing Asia, ADB Economic Working Paper Series, s.1-44.

Acemoğlu, D. ve Robinson, J.A. (2014), Ulusların Düşüşü: Güç, Zenginlik ve Yoksulluğun Kökenleri, (Çev. F. R. Velioğlu), İstanbul, Doğan Kitap.

Aizuddin, M., Seong, L.B., Yong D., Wen Huei C., Naga R., Kiesha and Kho C. (2018), Escalating Trade Tensions and Potential Spillovers to Malaysia, Bank Negara Malaysia Quarterly Bulletin, s.19-25.

Aksu, H., Aydemir, A.F., Karaköy, Ç. Yurttançıkmaz, Z.Ç. ve Emsen, Ö.S. (2018), Çin Ekonomisinde Büyümenin Sürdürülebilirliği: Yüksek Teknolojik Mal İhracatının Belirleyicileri, Cumhuriyet Üniversitesi İ̈F Dergisi, 19(2), s. 214-225. 
Altıntaş, N. ve Akpolat A.G. (2013), Tekstil Sektöründe Avrupa Birliği ile Türkiye Arasındaki Rekabet Analizi, Kafkas Üniversitesi Iktisadi ve İdari Bilimler Fakültesi Dergisi, 4(6), s. 33-42.

Amiti, M., Redding S.J. ve Weinstein D. (2019), The Impact of the 2018 Trade War on U.S. Prices and Welfare, NBER Working Paper, No: 25672, s. 1-39.

Balassa, B. (1965), Trade liberalization and revealed comparative advantage, Manchester School of Economic and Social Studies, 33, s.99-123.

Bekkers, E., Francosi J., Nelson D. (2019), Trade Wars and Trade Disputes: the Role of Equity and Political Support, World Trade Institute, s.1-70.

Bollen, J. and Rojan-Romagosa H. (2018), Trade Wars: Economic Impacts of US Tariff İncreases and Retaliations: An International Perspective, CPB Background Document, CPB Bureau of Economic Policy Analysis, s.1-44.

Cali, M. (2018). The Impact of the US-China Trade War on East Asia, VOX CEPR Policy Portal, (Erişim: 25.11.2019; https://voxeu.org/article/impact-us-china-trade-war-east-asia).

Caliendo, L. ve Parro, F. (2015) Estimates of the trade and welfare effects of NAFTA. Review of Economic Studies, 82(1), s. 1-44.

Chang, H.J. (2004), Kalkınma Reçetelerinin Gerçek Yüzü, (Çev. T. A. Onmuş), İstanbul, İletişim Yayınları.

Chang, H.J. (2015), Sanayileşmenin Gizli Tarihi, (Çev. E. Akçaoğlu), Ankara, Elif Yayınevi.

Charbonneau, K. B. and Anthony Landry (2018), The Trade War in Numbers, Bank of Canada Staff Working Paper, (57), s.1-40.

Chipman, J. (1969), Factor Price Equalization and the Stolper-Samuelson Theorem, International Economic Review, (10), s. 399-406.

Chong, T.T.L. ve Li, X. (2019), Understanding China-US Trade War: Causes, Economic Impact, and the Worst-Case Scenario, Lau Chor Tak Institute of Global Economics and Finance, The Chinese University of Hong Kong, Working Paper No:71, s.1-30.

Coase, R. H. ve Wang, N. (2015) Çin Nasıl Kapitalist Oldu?, (Çev. İ. Y1lmaz), Ankara, Tarcan Matbaası. 
Cory, N. (2018). "The Worst Innovation Mercantilist Policies of 2017”, Information Technology and Innovation Foundation, s. 1-36.

Çakmak, Ö. A. (2005), Açıklanmış Karşılaştırmalı Üstünlükler ve Rekabet Gücü: Türkiye Tekstil ve Hazır Giyim Endüstrisi Üzerine Bir Uygulama, Ege Akademik Bakış Dergisi, 51(2), s. 65-76.

Eaton, J., ve Kortum, S. (2002), Technology, Geography and Trade, Econometrica, 70(5), s.1741-1779.

Emsen, Ö. S. (2009), Роль политики либерализма и кейнсианства в Конфуцианском и Вебленистском обществах в преодолении последствий глобального финансового кризиса ("Küresel Finansal Krizin Sonuçlarını Elimine Etmede Konfüçyen ve Veblenci Toplumlarda Liberal-Keynesyen Politikaların Rolü’), Bankovskiy Vestnik: Ejemesaçnıy Bankovskiy Jurnal, (2), s. 27-37.

Ezell, S. J. and Atkinson, R.D. (2011) International Benchmarking of Countries' Policies and Programs Supporting SME Manufacturers, Information Technology and Innovation Foundation, s.1-55.

Gerni, C., Emsen, Ö.S., Gencer A.H. and Tosun B. (2018), Do Net Foreign Direct Investments Follow the Path of the Kuznets Curve and Even W-Curve?, Eurasian Business and Economics Journal, (13) s. 1-13.

Gros, D. (2019), This is not a Trade War, it is a Struggle for Technological and Geo-strategic Dominance, CESifo Forum, Vol (20), s. 21-26.

Guo, M., Liugang L.L., Sheng and Miaojie Y. (2018), The Day After Tomorrow: Evaluating the Burden of Trump's Trade War, Asian Economic Papers, 17(1), s. 101-120.

Kaynak, M. (2011) Kalkınma İktisadı, Gözden Geçirilmiş ve Genişletilmiş 4. Bask1, Ankara, Gazi Kitapevi.

Krugman, P. (1980), Scale Economies, Product Differentiation, and the Pattern of Trade, American Economic Review, s.950-959.

Lind, J. ve Press D.G. (2018) Markets or Mercantilism? How China Secures Its Energy Supplies, International Security, 42(04), s. 170204.

Liu, H. (2004), The Competitiveness of Canada's Poultry Processing Industry, Phd. Thesis, Canada, McGill University.

Mallick, M. (2018). "US-CHINA Trade War: Analyses of Deeper Nuances and Wider Implications", Vivekananda International Foundation, VIF Paper, September 2018. 
Meltzer, Joshua P. and Neena Shenai (2019), The US-China Economic Relationship: A Comprehensive Approach, Global Economy and Development at Brookings, American Enterprise Institute, s.1-24.

Melitz, M. J. (2003), The Impact of Trade on Intra-Industry Reallocations and Aggregate Industry Productivity, Econometrica, 71(6), s. 16951725.

Reziwanguli, Y. (2019), Çin’in ABD ve Türkiye Ekonomisi Karşısındaki Rekabet Gücü Üzerine Incelemeler, Atatürk Üniversitesi Sosyal Bilimler Enstitüsü Yüksek Lisans Tezi, Erzurum.

Seyidoğlu, H. (2013), Uluslararası İktisat: Teori, Politika ve Uygulama, Güzem Can Yayınları, İstanbul.

Steinbock, D. (2018). "U.S.-China Trade War and Its Global Impacts", China Quarterly of International Strategic Studies, 4(4), s.515-542.

Yean, T. Siew, A. Kam Jia Y. and Tee Beng A. (2019), US-China Trade War: Potential Trade and Investment Spillovers into Malaysia, Asian Economic Papers, 18(3), s.117-135.

Yurttançıkmaz, Z. Ç., Kabadayı, B. ve Emsen, Ö.S. (2014), Ekonomik Büyüme ve Rekabet Gücü Üzerine Türkiye Analizi, İstanbul University Econometrics and Statistics e-Journal, 21, s.21-46

Zhu, Zeyan, Yang Y. and Feng S. (2018), Trade War between China and US, Advances in Social Science, Education and Humanities Research (ASSEHR), s. 423-426.

World Bank (2019), World Development Indicators, Washington DC. 
